\title{
The Concept of Ethnicity and its Operationalisation in Cross-National Social Surveys
}

\author{
Jürgen H.P. Hoffmeyer-Zlotnik ${ }^{1}$ and Uwe Warner ${ }^{2}$
}

\begin{abstract}
This article describes the development of an instrument for the measurement of ethnicity in cross-national comparative survey research. First, we identify the data that must to be collected on ethnicity as a core variable. We then examine the way in which the national statistics offices of the European states and the major social science surveys handle this theme. And finally we present our own instrument for the measurement of ethnicity as a background variable.
\end{abstract}

\section{Problem formulation}

Social scientists define ethnicity as "a shared racial, linguistic, or national identity of a social group" (Jary and Jary, 1991: 151). However, the concept is understood differently from country to country. The two extreme definitions of "the people" and, hence, of ethnicity are:

a) The state strives to preserve the ethnic homogeneity of its population, and society sees itself as a community with common ancestry, culture and history. Nationality is defined in terms of the individual's (cultural) ancestry. Therefore, the only way to become a member of such a society is to be born into it (Heckmann, 1992: 212, translated by the authors).

b) The state defines itself in terms of persons with common interests, values, institutions and political convictions. Such a state, based as it is on the idea of common standards and assimilation, is amenable to immigration and naturalisation (Heckmann, 1992: 212, translated by the authors).

\footnotetext{
1 GESIS - Leibniz Institute for the Social Sciences, Mannheim, Germany

2 CEPS/INSTEAD, Differdange, Luxembourg
} 
The way in which individual countries define membership of the state, and the manner in which the composition of a country's population has developed over the course of its history has an important influence on how ethnicity is measured. A lot depends on whether the state is dominated by one ethnic group and whether this group emphasises the homogeneity of the groups (as for example in Germany and Switzerland);

- whether a state had colonies in the past (for example, the United Kingdom, France and Portugal) and, as a result, accepted - for a time at least - the immigration of inhabitants from these (former) colonies. In some cases, specific groups were even able to claim special rights. For example, up to 1998 Algerians born in Algeria before independence were entitled to apply for "reintegration into French nationality" (Ruf 2002a, 2002b);

- whether a state is or was a classical immigration country. In this case, since the state comprises a large number of ethnic groups, self-assignment to one or more ethnic groups is likely to be very subjective.

The ethnicity data collected both by academically-driven surveys and by the national censuses and micro-censuses vary to a certain extent from country to country depending on the concept of nationality, the naturalisation regulations and the ethnic composition of the population.

\section{Dimensions of "ethnicity" measured}

Social researchers are interested in the assignment of individuals to social groups. Individuals assign themselves subjectively to social groups by regarding social identity as the knowledge that they belong to certain groups (cf. Tajfel, 1978: 63). Billiet (2002: 386) concludes: "These identities therefore result from inter-group relations as do cognitive and affective representations of its dimensional constituents." Returning to the sociological definition of ethnicity furnished by Jary and Jary (1991: 151), we note that ethnicity can be broken down into three constituent dimensions: racial identity, linguistic identity, and national identity. If one endeavours to measure these three dimensions empirically, without giving subjective assignment too much leeway in the process, the ethnicity variable becomes very complex indeed.

\subsection{Legal membership of the state}

First of all, it must determined whether the respondent is a member (i.e. a citizen) of a state. In other words, his or her legal status must be clarified. For this reason, the question about "legal status" must come first. "Legal status" in the sense of citizenship is acquired by birth, naturalisation, legitimation or adoption (Schubert 
and Klein, 2006). Citizenship denotes the state of which a person is a member and in which he or she can and must assume the role of citizen with all the rights and obligations that this entails. In contrast to citizenship as membership of a state, nationality is a legal and protective relationship between a natural person and a state involving certain (nationality) rights, such as the right to vote, and certain obligations such as military service and tax liability. Citizenship can be acquired by descent (in Latin: jus sanguinis, the law of blood), that is, the child acquires the citizenship of its parents or one parent (if born out of wedlock, that of the mother). This is the case, for example in Austria, Switzerland and Germany. The alternative to jus sanguinis is the principle of birthplace (in Latin: jus soli, the law of soil) whereby the child acquires the citizenship of its country of birth. This is the case in the UK, for example. Hence, in order to be able to classify respondents according to legal status, it is important to record not only their citizenship(s) but also their country of birth and the citizenship of their parents.

As a rule, surveys differentiate between the long-established population (to which migrants can also belong), whose members usually also hold the citizenship of the majority, and immigrants, whose ethnic membership must be determined. Hence, roughly speaking, immigrants can have two degrees of legal status: citizen with full citizenship rights, or non-citizen with more or less limited rights. The more restricted a group's rights of social and political participation are, the more this group can be discriminated against, and the more likely it is that the members of the group will sub-stratify the social system of the majority.

However, in different countries, and at different times, there can be groups of people who receive special treatment. Although these people were born in a country other than their country of residence and hold the citizenship of their country of birth, they can obtain renaturalisation by (re)migrating. The ethnic German "repatriates" and the Algerian "remigrants" serve here as representative examples:

"Ethnic German repatriates" are a specifically German phenomenon. These repatriates are people with German cultural roots whose ancestors emigrated to Eastern Central Europe, Eastern Europe, South Eastern Europe and even Asia over the centuries. They began to repatriate to the Federal Republic of Germany from 1950 onwards. In certain circumstances, persons belonging to this category are granted German citizenship on the basis of their cultural roots because German Basic Law deems them to be of "German ethnic origin" (Schneider, 2005).

The second example relates to persons born in Algeria during French colonial rule (i.e. before 1962), who immigrated to France. Up to 1998, these Algerian immigrants were entitled to apply for "reintegration into French nationality" (Ruf, 2002a: 594; 2002b).

The consequences for an empirical classification of respondents according to legal status are as follows: First of all, respondents must be asked about their citizenship. The manner in which this citizenship was acquired must then be 
clarified. If the current citizenship was not acquired by birth, ethnic assignment can be carried out only if the country of origin is recorded.

\subsection{Limited rights to participate in the economic life of the country}

Initially, immigrants are foreigners with limited rights. These rights are limited to a greater or lesser extent by the individual's residential status. Residential status represents the entitlement to reside in a particular country. It regulates the length of stay and the conditions to which the immigrant is subject. Hence, residential status can severely restrict a person's autonomy of action.

A citizen who has all the rights and obligations of citizenship is also entitled to take up any available paid employment for which he or she is qualified. As a rule, an immigrant who is not yet a citizen of the host country has less rights in this regard. Different countries have different categories of work permit. However, only two of these categories are suitable for cross-national comparison purposes: Does the immigrant have a permit entitling him/her to take up paid employment? Yes or No. This question does not measure freedom of settlement, for example. However, this is not necessary because the dichotomy suffices to determine whether the respondent is entitled to earn his or her own living and is thus in a position to participate in society as a consumer.

The consequences for the empirical classification of respondents according to opportunity to participate in the economic life of the country are as follows: Persons who are not citizens of the surveying country must be asked about their residential status and whether or not they have a work permit.

\subsection{Ethnic self-assignment as assignment to a cultural background}

Ethnic self-assignment serves to determine national identity in the sense of cultural identity based on a cultural nation. "Cultural nation" is a sociological concept that is more subjective and ambiguous in its meaning than "political nation". A cultural nation represents a group of people who, by emphasising their own cultural attributes, develop a group-specific sense of togetherness. In this sense, ethnicity is "constantly re-constructed in interaction" (Billiet, 2002: 388). However, "An individual does not have one identity, but multiple identities which are negotiated with others through interaction". Ethnic identity emerges when an individual's social context underscores aspects that are related to the categorisation of individuals along ethnic lines (Leets et al.:14, cited by Billiet, 2002: 391).

The three main types of ethnic group can be defined as follows: 
- Type 1: Large ethnic groups who are politically unified in a nation but who are culturally separate even in terms of language. This is the case with the four ethnic groups in Switzerland, the three ethnic groups in Belgium, the four main ethnic groups in Spain, and the four formerly independent countries that now make up the United Kingdom.

- Type 2: Recognised ethnic minorities with guaranteed cultural independence. As a rule, these ethnic minorities became part of a nation as a result of the foundation of a nation state, a post-war border shift, or by immigration in the past (sometimes several centuries ago).

- Type 3: Immigrants and the descendants of immigrants who arrived over the last 150 years from all parts of the globe. In Europe, this group comprises immigrants from former colonies, migrant labourers recruited as blue-collar workers since the beginning of the Industrial Revolution, immigrants who are recruited nowadays as white-collar workers, migrant workers who take advantage of freedom of movement within the European Union, and ethnic German repatriates. Outside Europe this group comprises immigrants and the descendants of immigrants and of persons who were brought to the country in question as slaves.

As these three types are of interest here, it is necessary to specify what is meant by ethnic identification: "Ethnicity and ethnic identification, whether stable or transient, fundamental or peripheral to the individual's concerns include a measure of self-assignment to a socially-derived category, which only exists by opposition to other social categories. Furthermore, such self-assignment is per force affectively-loaded. Both the categorical assignment and its valence are, therefore, necessary elements of ethnicity and its measurement" (Leets et al.: 21, cited by Billiet, 2002: 392).

In order to be able to empirically classify respondents according to ethnic selfassignment, they must be asked which of the country's ethnic groups they identify themselves with. When drawing up the list of categories, it will of course be necessary to begin with Type 1 above, i.e. the large autonomous ethnic groups in the country (for example in Switzerland, Belgium, the UK, and Spain). However, when it comes to Type 2, it will not be possible to include all the recognised ethnic minorities (in Germany, for example, the Danes, the Frieslanders, and the Sorbians). As a rule, only a small number of members of these minorities are among the respondents. Hence these groups are irrelevant for the analysis except in the case of France where the ethnic groups in question (for example, the Occitans) are so large that they are the equivalent of the large autonomous ethnic groups in countries such as the UK or Spain. Besides the majority ethnic group, it is necessary to include all those minorities that can be subsumed under broad categories such as immigrants from other EU countries, European immigrants from non-EU countries, immigrants from the (former) colonies, immigrants from Asia divided into three sub-categories etc (Type 3 above). 
In countries in which ethnic self-identification is the norm in national censuses, a number of major categories are distinguished. In the UK, for example, these categories are "White", "Black or Black British", "Asian or Asian British", "Mixed", "Chinese" and "Other" (Office of National Statistics et al. 2004: UK Census, 2001). In the USA there are five main categories. Instead of including a "Mixed" category, the USA allow respondents to choose two or more race categories. Since a separate "Mixed" category can only combine the main categories with each other, it would appear expedient to restrict respondents to a maximum of two categories. Self-assignment to up to four categories, as the U.S Census permits, should be avoided. Researchers should make sure that they do not forget to include a category for the majority ethnic group in the country. Otherwise the "Mixed" category would not make sense.

It is also important to list all the large groups who are visible in society, identifiable in surveys, and who are considered problematic from the point of view of integration.

\subsection{Immigrant background}

Persons with an immigrant background are either immigrants or their descendants. In other words, this group comprises all persons ...

- who migrated from one country to another

- who were born as "foreigners" in the surveying country, and

- all persons who were born as citizens in the surveying country but have at least one parent who migrated from another country.

This means, first, that those persons who actually migrated themselves must be identified, irrespective of whether they are still "foreigners" or not. Then, under "descendants" who are no longer statistically visible as "foreigners", the migrant parents or parent must be identified, and, in the case of specialist surveys, also the migrant grand-parents. However, where ethnicity is a background variable, it suffices to go back as far as the parents.

- In Germany, you have the "ethnic German repatriates" (Bade and Oltmer, 1999), who are the descendants of German settlers who left Germany in the $12 / 13$ th and 18 th centuries.

- In France, you have the Algerians who were born in Algeria before 1962 (the year of independence) and who were thus French nationals. Up until 1998, they were entitled to apply for "reintegration into French nationality" (Ruf, 2002a: 594).

- In Turkey and Greece, these returning migrants are "guest workers" remigrating to their native country. "Guest workers" (Akgündüz, 2008) are labourers who migrated from structurally weak regions to highly industrialised countries in order to earn their living there for a limited 
period of time (Messere, 2008). These "guest workers" are wanderers between cultures who keep the option of returning to their native country open - at least as an ideal. Host countries that favour the "rotation principle" reserve the right, on one legal basis or the other, to send the "guest workers" back to their countries of origin when their labour is no longer needed. Incentives for remigration are frequently of a financial nature (Kaiser, 1985).

On the other hand, you have persons, or groups of persons, who were expelled from their native country.

- "Expellees" are persons who are forced by state measures to leave their region of origin or their native country for ethnic, religious, social or political reasons (Marrus, 1985; Wren, 1995; Hoffmann, Kraus and Schwartz, 2000).

- The category "expellees" also includes persons who were displaced after a border shift. This was the case, for example, in the Balkans, where a number of new states were established in the 1990s after the collapse of Yugoslavia. Groups of persons in Germany, Poland and Russia suffered a similar fate as a result of border shifts after the Second World War.

In order to empirically classify respondents according to immigrant background, the country of origin of the father and mother must be recorded. Because persons with an immigrant background are often no longer foreigners, it is necessary to measure immigrant background separately.

\subsection{Integration of immigrants in the host society}

The integration dimension can be viewed as a supplement to the immigrantbackground aspect. The language that a person speaks at home in a relaxed atmosphere is a key indicator of integration. The mother tongue is important for a person's psychological identity and for identification with his or her own culture and origins.

"Mother tongue" is defined as "the first language which the child learns as distinct from the foreign language that is learned later. In general, a person has only one mother tongue. When people are bilingual, they often do not have an equal command of both languages but rather use them in different contexts" (Meyers Lexikon online, 2009, translated by the authors). According to Alba (2005), the first generation of immigrants learn just enough of the language of the host country to get by. They speak their mother tongue at home. Their children, the second generation, learn their mother tongue at home. However, at school, on the street and with their friends they use the language of the host country. Hence it quickly becomes the language in which they answer their parents at home. The 
third generation is then the first generation to speak the language of the host country as their mother tongue.

For an empirical classification of respondents according to their level of integration in the host society, the language that people with an immigrant background speak at home with their family and friends is one of the strongest indicators of their level of cultural integration.

\section{Measurement of ethnicity in the census questionnaires of the $\mathbf{E U}$ member states}

We evaluated the questionnaires of the population censuses (in Germany, the micro-census) of 23 EU member states and Switzerland. In the case of registerbased censuses (Denmark, Norway and Finland), we developed categories on the basis of the information issued by the national statistics offices.

As can be seen from the list of individual indicators in the table below, 19 of these 26 EU member states record "citizenship" in the sense of legal membership of the state, 9 countries ask about "nationality" in the sense of membership of "the people" who constitute the national state; 5 of these countries record both citizenship and nationality. Only 9 EU member states ask about residential status. No census features a direct question about work permits. However 5 census sheets record residential status. A residence title gives the holder rights that do not have to be recorded separately by the national statistics offices. While the work permit is a variable of interest to social scientists, it does not appear to be of interest for official statistics purposes. Visible ethnicity is measured in only two EU member states whereas eight others request respondents to self-assign their ethnic group.

Most of the censuses measure immigrant background. Nineteen EU member states do so by asking for the country of birth of the respondent, and ten countries ascertain the former place of residence. Five of these countries ask for both. Ten countries also record the date of entry or the length of residence. The country of birth of the parents is recorded in seven countries, and the place of residence of the parents is recorded in three countries. Five countries ask about the reasons for immigration.

As a rule, citizenship, defined as the legal membership of a state, is measured by requesting the respondent to name the state of which he or she is a member. Some countries endeavour to a greater or lesser degree to record all the states of which the respondent is a citizen. For example:

What is ...'s citizenship?

- Cypriot

- Other (specify):

Source: Republic of Cyprus, Statistical Service (2001): Census of Population 2001. 
Citizenship - in case of double citizenship, state both:

Source: Czech Statistical Office (2001): 2001 Census Questionnaire

In exceptional cases, for example in Italy, all those who are not members of the surveying state are assigned roughly to groups that are legally relevant from that state's point of view: "citizen of an EU member state" or "citizen of a state outside the EU" (Istat, General Population and Housing Census 2001):

- Italian citizenship

- citizen of an EU member state

- citizen of a state outside the EU

In the case of a register-based census, the only data that can be collected are those that are recorded in the population register for all the members of the residential population. Where a person has more than one citizenship, only one is registered. The citizenship of the surveying country has priority (see: Statistics Norway, 2001).

When asking about citizenship, some countries also want to know how it was acquired:

- French by birth (including through renaturalisation)

- French through acquisition (people who have become French through naturalisation, marriage, declaration, or when reaching majority).

Source: INSEE (1999): recensement 1999

In some countries, the political term "nationality" is equated to the legal term "citizenship":

Nationality:

- Luxembourgish

- Foreign: state nationality

- No nationality (stateless)

Source: Grand Duchy of Luxembourg, Statec, (2001): General Population Census 2001.

However, the nationality concept is not only defined in political terms (national of a state) but also in ethnic terms (membership of an ethnic or descent group). Hence, in some countries in which there are several ethnic groups, both citizenship and nationality are ascertained.

Nationality is the declarative (based on the subjective feeling) individual feature of each human being, expressing his/her emotional (sentimental) connection, cultural or genealogical (considering the origin of parents) with given nation.

Source: Central Statistical Office (2007): Demographic Yearbook of Poland

Nationality is referred to as the person's affiliation to the nation or ethnic minority. 
Source: Statistical Office of the Slovak Republic (2007a): Census of Population and Housing

The place of birth is of key importance in those countries in which the principle of birthplace (jus soli) applies and where, as a result, membership of the state is determined by the place of birth. In addition to two equally common simple questions either about the place of birth (more broadly referred to as the country of birth) or the place of residence of the mother at the time the target person was born, two more restrictively worded questions were found:

Place of birth (mother's place of residence at the time the person was born).

Mother's (permanent) place of residence at the time the person was born is regarded as the place of birth not the location of the maternity hospital.

Source: Statistics Estonia (2000): Population and Housing Census

Limited rights is the second legal-status question after citizenship. On the one hand, the term "residential status" covers all those groups who are accorded a special status on economic, political or humanitarian grounds. As a rule, these persons are migrant workers, students, refugees or asylum seekers. Instead of listing groups, types of residence permit can be specified.

Lithuania distinguishes three categories of person:

- the immigrant, "a foreigner who has got temporary residence permits for one year and longer"

- the refugee, defined as a "considered foreigner who left the country of his/ her citizenship or the country of his / her permanent residence in order to avoid prosecution because of his / her political views, national, racial or religious affiliation to whom the refugee status was granted in the Republic of Lithuania", and

- the political asylum seeker, defined as "a considered foreigner who arrived in our country and applied for the refugee status."

(Statistics Lithuania, 2001).

If membership of an ethnic group rather than citizenship is to be recorded, then ethnic self- assignment is asked about. This can either be done via an open question or by means of a show card featuring all the relevant ethnic groups in the country.

Ethnicity (show card: Lithuanian, Russian, Polish, Belorussian, other, not indicated)

Source: Statistics Lithuania, 2001b

However, ethnicity is often ascertained by asking about "ethnic nationality" (for example, in Estonia), "ethnic/religious group" (for example, in Cyprus) or "ethnic or cultural background" (for example, in Ireland). Assignment is carried out by the respondent. 
Table 1: Elements found in the population census 1999/2000/2001/2002 (for Ireland 2005 and Malta 2006) by country.

\begin{tabular}{|c|c|c|c|c|c|}
\hline \multirow{2}{*}{\begin{tabular}{|l|}
\multicolumn{1}{|c|}{ Country } \\
In population census \\
$1999 / 2000 / 2001 / 2002$, \\
alternatively \\
$2005 / 2006$
\end{tabular}} & \multicolumn{3}{|c|}{ legal criteria } & \multicolumn{2}{|c|}{ ethnicity } \\
\hline & citizenship & nationality & $\begin{array}{c}\text { residential } \\
\text { status }\end{array}$ & $\begin{array}{l}\text { visible } \\
\text { ethnic } \\
\text { groups }\end{array}$ & $\begin{array}{c}\text { self- } \\
\text { assigned }\end{array}$ \\
\hline$B G$ & dichotomous & & & $x$ & \\
\hline EE & open detailed & & & & $x$ \\
\hline $\mathrm{FI}$ & register based & & & & \\
\hline FR & dichotomous & detailed & $\mathrm{X}$ & & \\
\hline GR & open detailed & & & & \\
\hline IE & & open detailed & & & $x$ \\
\hline LV & & & & & $x$ \\
\hline LT & open detailed & categorised & $x$ & & $x$ \\
\hline LU & & open detailed & & & \\
\hline MT & open detailed & & & & \\
\hline NL & register based & & $X$ & & \\
\hline AT & open detailed & & & & \\
\hline RO & open detailed & & $\mathrm{X}$ & & $\mathrm{X}$ \\
\hline SE & & & & & \\
\hline SK & open detailed & open detailed & & & \\
\hline SI & & open detailed & & & $x$ \\
\hline ES & & open detailed & & & \\
\hline CZ & 2 categories & open detailed & $\mathrm{X}$ & & \\
\hline HU & open detailed & & & & $x$ \\
\hline UK & & & & & $\mathrm{x}$ \\
\hline CY & dichotomous & & & $x$ & \\
\hline \multicolumn{6}{|l|}{$\begin{array}{l}\text { In statistical invest- } \\
\text { igation } 2007 / 2008\end{array}$} \\
\hline DK & register based, & & & & \\
\hline DE & open detailed & & $x$ & & \\
\hline IT & grouped & & $x$ & & \\
\hline PL & 3 categories & categorised & $x$ & & \\
\hline PT & 5 categories & & $x$ & & \\
\hline \multicolumn{6}{|l|}{ Non-EU countries } \\
\hline Norway & register based & & & & \\
\hline Switzerland & open detailed & & $\mathrm{X}$ & & \\
\hline
\end{tabular}




\begin{tabular}{|c|c|c|c|c|c|c|}
\hline \multirow[b]{2}{*}{\begin{tabular}{|l|} 
\\
In population \\
census $1999 /$ \\
$2000 / 2001 / 2002$, \\
alternative \\
$2005 / 2006$ \\
\end{tabular}} & \multicolumn{2}{|c|}{ respondent's } & \multicolumn{4}{|c|}{ immigrant background } \\
\hline & $\begin{array}{l}\text { birth } \\
\text { place }\end{array}$ & $\begin{array}{c}\text { prior } \\
\text { resi- } \\
\text { dence }\end{array}$ & $\begin{array}{c}\text { parents' } \\
\text { birth } \\
\text { place } \\
\end{array}$ & $\begin{array}{l}\text { parents' } \\
\text { place of } \\
\text { resi- } \\
\text { dence } \\
\end{array}$ & $\begin{array}{l}\text { arrival } \\
\text { date, } \\
\text { dura- } \\
\text { tion of } \\
\text { stay }\end{array}$ & $\begin{array}{c}\text { reasons } \\
\text { for } \\
\text { migration }\end{array}$ \\
\hline$B G$ & $x$ & & & & $x$ & \\
\hline EE & $x$ & & $x$ & $x$ & & \\
\hline $\mathrm{FI}$ & & & & & & \\
\hline FR & $x$ & $\mathrm{x}$ & & & & \\
\hline GR & & $x$ & & & $x$ & $x$ \\
\hline IE & $x$ & $x$ & & & & \\
\hline LV & & $x$ & & & & \\
\hline LT & $x$ & & & & & \\
\hline LU & $x$ & & & & & \\
\hline MT & $x$ & $x$ & & & & \\
\hline NL & $x$ & & $x$ & & $x$ & $x$ \\
\hline AT & $x$ & & & & & \\
\hline RO & $x$ & & & & $x$ & $x$ \\
\hline SE & & & & & & \\
\hline SK & $x$ & & & & & \\
\hline SI & & $x$ & & & $x$ & $x$ \\
\hline ES & $x$ & & & & $x$ & \\
\hline$C Z$ & & & & & & \\
\hline $\mathrm{HU}$ & $x$ & $x$ & $x$ & & $x$ & \\
\hline UK & $x$ & & & & & \\
\hline CY & $x$ & $x$ & $x$ & & & \\
\hline \multicolumn{7}{|l|}{$\begin{array}{l}\text { In statistical } \\
\text { investigation } \\
2007 / 2008\end{array}$} \\
\hline DK & $x$ & & $x$ & $x$ & & \\
\hline DE & $x$ & $x$ & & $x$ & $\mathrm{x}$ & \\
\hline IT & & & $x$ & & $x$ & $x$ \\
\hline PL & $x$ & $x$ & & & $x$ & \\
\hline PT & & & $x$ & & & \\
\hline \multicolumn{7}{|l|}{ Non-EU countries } \\
\hline $\begin{array}{l}\text { Norway } \\
\text { Switzerland }\end{array}$ & $\begin{array}{l}x \\
x\end{array}$ & & $x$ & $x$ & $x$ & $x$ \\
\hline
\end{tabular}




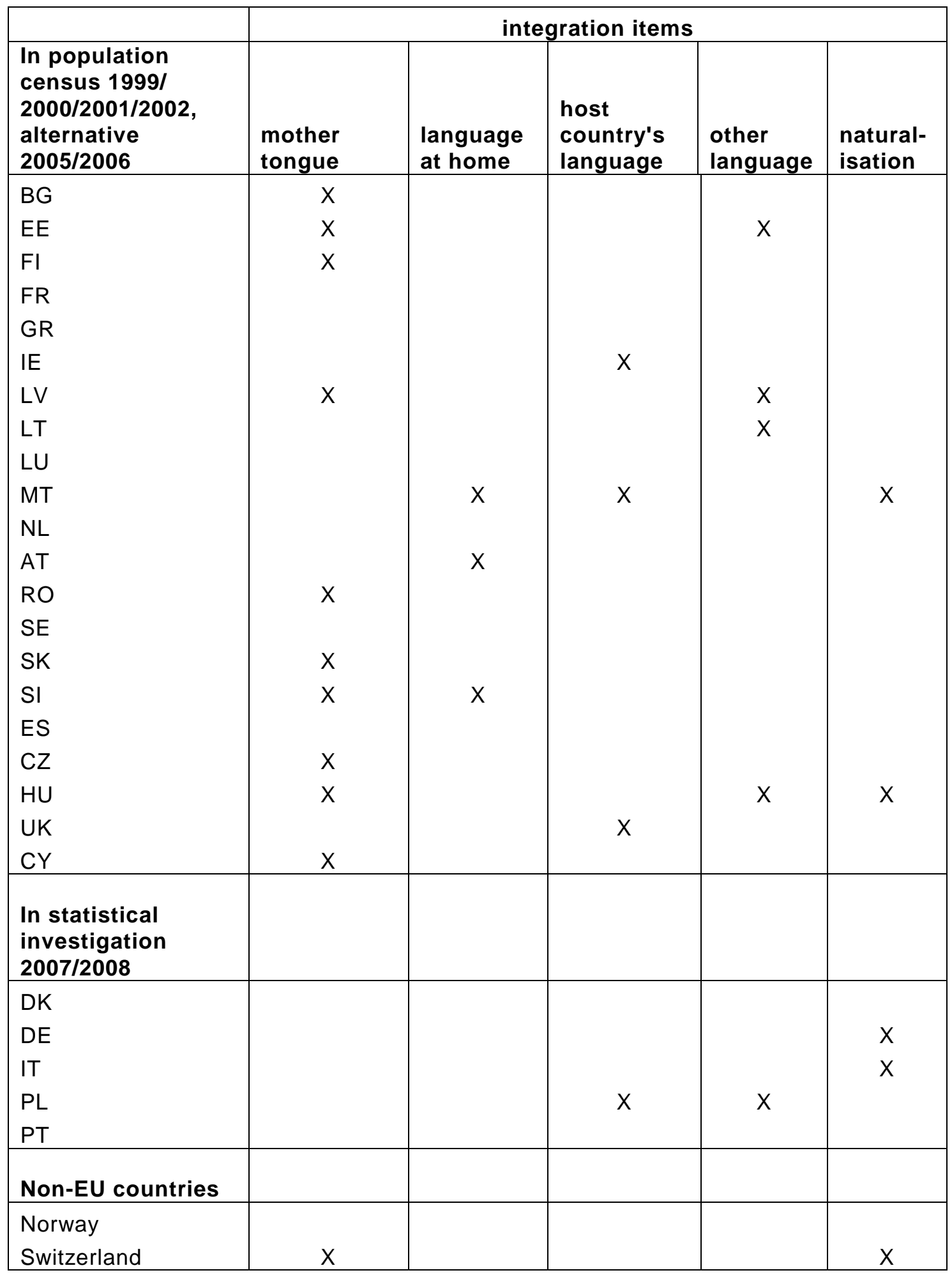


The task of self-assigning an ethnic or cultural group is explained in the census fact sheet. In Hungary, for example, the explanation is as follows: "From the point of view of national group belonging in Hungarian population censuses, every person is counted as belonging to the national group to which he/she declared to belong, free of all influences and without regard to his/her mother tongue" (Hungarian Central Statistical Office 2001: Population Census 2001). Slovenia even refers to the Constitution (Article 61): "In accordance with the constitutional principles of the equality of nations and ethnic groups, a person has a right to declare his/her ethnic affiliation" (Republic of Slovenia, 1991: OJ RS, No. 33/91-I, Article 61).

The first restrictive criterion relates to the place of residence of the mother at the time of the respondent's birth. This can differ from the place of birth and hence the principle of birthplace, jus soli, may be undermined. The second restriction defines the country of birth in terms of that country's current borders. In regions in which federations fell apart and new countries arose, this may make sense. However, in regions in which post-war border shifting occurred and populations were expelled or resettled, this procedure can be problematical. If intended for general use, both restrictive criteria should be implemented with caution.

Besides the place/country of birth, a number of other indicators are important for the establishment of an immigrant background:

- The country in which the target person was living before he or she entered the present country of residence for the first time. This country need not be identical with the person's country of origin:

In which foreign country did you live before you settled in Greece?

Source: General Secretariat of the National Statistical Service of Greece, 2001

From which country did you first move to Slovenia?

Source: Statistical Office of the Republic of Slovenia, 2002

- The next indicator for an immigrant background is how long and since when the target person has been living in his or her present country of residence. (This is also an - albeit unreliable - indicator for residential status and integration.)

Bulgaria asks for the "year of the last migration" (Republic of Bulgaria, National Statistical Institute, 2001)

Greece asks: "In which year did you settle in Greece?" (General Secretariat of the National Statistical Service of Greece, 2001)

- A last indicator for an immigrant background is the place or the country of birth of the parents. If the country of birth of the parents or of one parent is not the present country of residence, there are grounds to assume that the target person has an immigrant background. However, this neither means that the target person is a first or second-generation immigrant nor that the parents must have been foreign citizens (cf. the remigration of migrant workers to their 
native countries, ethnic Germans who resettled in Germany, and Algerians who were "reintegrated into French nationality").

Where was ...'s father born?

- Cyprus

- Abroad (specify country):

Where was ...'s mother born?

- Cyprus

- Abroad (specify country):

Source: Republic of Cyprus, Statistical Service, 2001: Census of Population 2001.

In addition to the country of origin of the parents, some countries ask about the parents' place of residence. This can serve to establish whether the target person belongs to the first or to a subsequent migrant generation.

Do your parents or does one of your parents still live in the country of origin?

Yes / No

Source: Statistische Ämter des Bundes und der Länder, 2008: translation by the authors

The final dimension, integration of immigrants in the host society, is measured in European censuses by the mother tongue. This is defined as the first language spoken in early childhood (Statistics Estonia, 2000), the language spoken most often at home, or the language which the target person speaks "fluently".

What language does... speak fluently?

Source: Republic of Cyprus, Statistical Service, 2001: Census of Population 2001.

Mother tongue - indicate the language spoken by your mother or guardian when you were a child?

Source: Czech Statistical Office, 2001: 2001 Census Questionnaire.

What is your mother tongue?

One variant of answers is recorded. The language which was the first language spoken in early childhood and which is usually the language that the person commands best is recorded. Person's mother tongue should not necessarily coincide with his/her ethnic nationality.

What other languages do you speak?

Source: Statistics Estonia, 2000: Population and Housing Census

\section{Measurement of ethnicity in cross-national comparative surveys}

In academically-driven cross-national comparative survey research the ethnicity variable is difficult to handle. The data in the International Social Survey Programme (ISSP) are collected by a subset of the participating countries. 
Because characteristics of interest to the surveying country are asked about, and because these characteristics are not necessarily comparable with those surveyed in other countries, the ISSP does not currently collect any ethnicity-related data (Zentralarchiv für empirische Sozialforschung, 2004: ISSP 2004. Citizenship. Codebook).

In the Eurobarometer, the ethnicity question is limited to asking about nationality (Eurobarometer, 2005).

The range of ethnicity data collected in the European Value Study (EVS) (2008) is somewhat broader. In addition to citizenship, respondents are asked about nationality, which is defined in the interviewer instructions as follows: "Nationality is passport!" Other variables measured include the country of birth of the target person and that of his or her father and mother, and the target person's length of residence in the host country.

In a comprehensive battery of questions, the European Social Survey (ESS) asks about the respondent's citizenship (in contrast to the Eurobarometer, which asks about nationality, and the EVS, which asks about nationality and citizenship), his or her country of birth, the language(s) spoken most often at home, and whether he or she is a member of an ethnic minority in the surveying country (ESS, 2004; 2006a). Finally, the country of birth of the target person's mother and father are ascertained. Hence the ESS measures all the relevant variables with the exception of residential status and length of residence.

The only cross-national differences in wording that influence the interview are to be found in the supplementary information in the national questionnaires explaining or clarifying individual items. For example, in the German version of the ESS questionnaire, German territorial borders are defined as follows: "This means the territory of present-day Germany since reunification in 1990 and territories which were part of German national territory at the time of the respondent's birth (or the time of birth of the respondent's father or mother)" (ESS, 2006b: ESS DATA. ESS3-2006. Questionnaire: Germany, questions C27, C33, C35). The Belgian questionnaire defines ethnic identification as follows: "'Faire partie' se rapporte à l'attachement ou à l'identification. 'Les minorités ethniques' sont les groupes qui sont originaires d'un autre pays. Ces groupes peuvent avoir une même nationalité (mais pas la nationalité belge), ces groupes peuvent avoir une même religion, une même culture, une même provenance et/ou une même langue" (ESS, 2006b: ESS DATA. ESS3-2006. Questionnaire: Belgium, French, question C32). The questionnaire of the Netherlands defines "ethnic minorities" in the following way: "Daaronder verstaan we etnische groepen zoals Turken, Marokkanen, Surinamers en Antillianen die oorspronkelijk niet afkomstig zijn uit Nederland" (ESS, 2006b: ESS DATA. ESS3-2006. Questionnaire: Netherlands, question C32). In the Danish questionnaire, on the other hand, the ethnicity question defines "belonging" to an ethnic minority as follows: "'Tilhører' betyder her at være tilknyttet eller identificere sig med gruppen" (ESS, 2006b: ESS DATA. ESS3-2006. Questionnaire: Denmark, question C32). 
When supplementary information in the national questionnaires serves to emphasise national idiosyncrasies, then care must be taken to avoid shifting the meaning of the question stimulus in the process. However, when the instructions for the respondent are at odds with the instructions in the blueprint - as is clearly the case in the German example above -, then what is measured is not what is supposed to be measured. There is something to be said for both definitions (the country of birth defined in terms of the current borders or in terms of the borders at the time of birth). After both World Wars, Germany had to relinquish territory. Therefore the country of birth of persons who were born, for example, in Danzig (Gdansk) or Koenigsberg (Kaliningrad) before 1945 was Germany then and is now Poland or Russia. In the case of Slovenia and Croatia, on the other hand, it makes sense to define the country of birth in terms of current borders because these countries did not come into existence until independence in 1991. However, the war that broke out after independence forced ethnic groups to migrate with the result that not all those who consider themselves to be ethnically Croatian going back several generations were actually born in what is now Croatia. These two examples show that both definitions have their merits. However, all participating countries must adhere to one and the same definition.

\section{Consequences for the development of an instrument for use in cross-national comparative survey research}

Citizenship (in the case of more than one citizenship: list all) as the dimension for legal membership of a state is surveyed in nearly all censuses and surveys. It is more important to ask about the legal status of "citizenship" than the ethnic or political status of "nationality". However, in some countries (for example, France) the concept of nationality covers legal status. Hence, the functionally equivalent concept should be used.

It is essential to ascertain the country of birth for two reasons. On the one hand, in countries in which jus soli applies, the right to citizenship is derived from the country of birth. And, on the other hand, as mentioned earlier, there are specific groups of persons who are eligible for "renaturalisation" (in Germany, ethnic Germans from Eastern Europe etc; in France, Algerians born in Algeria before independence). Other countries may have (had) similar provisions.

The determination of the country of birth poses a problem when the national borders of the country in question have shifted in the meantime. On the one hand, we must be mindful of post-war border shifts. For example, Poland's western and eastern borders, Slovakia's eastern border, and Germany's eastern border were redrawn after the Second World War. Attention must also be paid to temporary border shifts that can occur during wars, as was the case during the Serbo-Croatian 
War. The breakup of federations into individual countries, for example after the dissolution of the Union of Socialist Soviet Republics or the partitioning of Yugoslavia and Czechoslovakia, also poses a problem when it comes to determining the country of birth. Even greater problems are posed by secessions that are not internationally recognised, as in the case of Transnistria, or the temporary de facto state of the Republic of Serbian Krajina during the SerboCroation War.

Official European statistics define the country of birth on the basis of current borders $^{3}$. The European Social Survey also implicitly advocates this practice because the main questionnaires, which serve as a blueprint for the translation of the national questionnaires, do not contain any further specifications (cf. for example, the European Social Survey, 2006a, C27). In the case of Germany's ESS questionnaire, the demarcation of the borders at the time of the respondent's birth is what counts ${ }^{4}$. Where jus soli applies, the fact that a territory belongs to a national state becomes relevant for the respondent from the date of his or her birth onwards. Hence, in connection with ethnicity as a complex of themes in population surveys, this date alone is decisive. In the case of countries or federations that have since broken up, for example the CSSR or the Federal Republic of Yugoslavia, it would make sense to record both the country of birth, for example Yugoslavia, and the constituent republic, for example Croatia. Reference to current borders can sometimes convey the impression that the respondent migrated to another country, which was not, however, the case. Hence this impression should be avoided.

It is also important to ascertain the length of residence in the present country of residence because this influences the residential status in that country. These four variables (citizenship, self-assigned ethnicity, country of birth, and length of residence) provide the central framework for the measurement of ethnicity. However, these variables do not cover all the relevant sociological characteristics.

As social scientists, we should be interested not only in the citizenship that our target person holds, but also in how and when it was acquired. And, in the case of non-citizens, we should want to know what rights and opportunities the person has to participate in the economic life of the country. It is therefore necessary to ask about residential status. However, this question need not cover all possible residence titles but only those that are of relevance to the research question.

\footnotetext{
${ }^{3}$ The Regulations (EC) No 862/2007 of the European Parliament and of the Council of 11 July 2007 on community statistics on migration and international protection and repealing Council Regulation (EEC) No 311/76 on the compilation of statistics on foreign workers: Article 2, 1 (e): " 'country of birth' means the country of residence (in its current borders, if the information is available) of the mother at the time of the birth or, in default, the country (in its current borders, if the information is available) in which the birth took place".

4 "This means the territory of present-day Germany since reunification in 1990 and territories which were part of German national territory at the time of the respondent's birth" (ESS, 2006b: ESS DATA. ESS3-2006. Questionnaire: Germany, questions C28)
} 
Limited rights are rarely asked about in censuses, while in surveys the question is never posed. However, as a sociological concept, limited rights are significant because they regulate access to social and economic resources.

Ethnic status as the indicator for the dimension of cultural background must be measured separately. It is important to bear in mind that ethnic status is primarily based on subjective assignment, be it self-assignment or interviewer assignment. In our survey, respondents self-identify their ethnicity.

Immigrant background is also of relevance to social scientists because second-generation immigrants may not necessarily be integrated. The minimum information required to determine an immigrant background is the country of birth of both parents. One key indicator for integration is the language that the target person speaks most often at home. However, in order to find out if the person is a "wanderer between two cultural worlds", it is necessary to ask whether a second language is spoken at home.

In the censuses in the majority of European countries, the mother tongue or the language spoken at home is considered to be an indicator of integration in the host society. Only a few censuses feature a direct question about the command of the language of the host country.

The above deliberations yield an instrument comprising six questions with sub-questions:

1) for all respondents: what citizenship(s) are held and how and when were they acquired

2) for foreigners only: what is the residential status and when was it acquired

3) for all respondents: self-assignment to an ethnic group

4a) for all respondents: country of birth

4b) for persons born abroad: since when the person has been living in the present country of residence

5) for all respondents: country of birth of the father and mother

6) for all respondents: the language that is spoken most often at home.

\section{Proposal for an instrument to measure ethnicity as a background variable}

The following set of questions serves primarily to measure ethnicity as a sociodemographic background variable. Nonetheless, it is a very comprehensive instrument because migration researchers' specialised themes call for greater depth. However, not all the questions must be asked each time. As discussed in Chapter 2, ethnicity is a multi-dimensional concept. When designing a crossnational comparative survey, researchers must first determine, on the basis of their research question, what dimensions should be measured. 
The questions under (1) below deal with the concept of citizenship. It is necessary to determine what citizenship(s) the person holds, and how and when the citizenship of the surveying country was acquired. (In random samples, the survey population consists of all persons resident in the country regardless of citizenship or legal status.)

The questions under (2) below record in four relevant categories the residential status of persons who are not citizens of the surveying country but who are members of the resident population and hence of the survey population.

Question (3) asks the respondent to self-assign his or her ethnic group membership on the basis of a country-specific list of categories.

The questions under (4) below ascertain the target person's country of birth. They also serve to identify the person's immigrant background as do the questions under (5) below, which record the country of birth of the person's father and mother.

The questions under (6) below ascertain the language(s) spoken at home and are therefore an indicator of integration.

1. Are you a citizen of [this country]?

Yes $\quad$ go to question 1.1

No $\quad$ go to question 1.4

1.1. What other citizenship do you hold?

a. No other citizenship

b. Write in the second citizenship:

c. Write in the third citizenship:

(Coded as ISO3166-1 and first citizenship automatically entered using the ISO3166-1 of the country in question)

1.2. By which legal procedure did you become a citizen of [this country]?

By birth

Through (one of) my parents

go to question 3 .

On reaching the age of majority

By marriage

go to question 3 .

By adoption

go to question 1.3

By naturalisation

go to question 1.3

go to question 1.3

By descent

go to question 1.3

go to question 1.3

The list of response categories can be extended in order to cover countryspecific provisions

1.3. In what year did you obtain the citizenship of [this country]?

Around: go to question 3. 
1.4. What citizenship do you hold?

a. Write in the first citizenship:

b. Write in the second citizenship:

c. Write in the third citizenship:

d. Stateless person

(Coded as ISO3166-1)

2. What residential status do you have?

I hold an unlimited residence permit.

I hold a limited residence permit and a work/employment permit

I hold a temporary residence permit but no work/employment permit

I am a refugee / asylum-seeker

The list of response categories can be extended in order to cover countryspecific provisions

2.1. In what year did you acquire this residential status?

Around:

3. To which ethnic group in [this country] do you belong?

Country-specific list of groups

Show card based on the demographic structure of the country and featuring the main visible ethnic groups.

4. Were you born in [this country]?

Yes go to question 5.1.

No go to question 4.1.

4.1. In what country were you born?

Write in the country of birth:

(Coded as ISO3166-1: If answer to 4 is yes, automatically enter the ISO3166-1 of this country)

4.2. In what year did you first come to [this country]?

Around:

5.1. Was your father born in [this country]?

No, he was born in: (Write in the country and code as ISO3166-1)

Yes

(automatically enter the ISO3166-1 of this country)

5.2. Was your mother born in [this country]?

No, she was born in: (Write in the country and code as ISO3166-1)

Yes

(automatically enter the ISO3166-1 of this country)

6.1. What language do you speak most often at home?

Write in the most frequently spoken language:

(Coded as ISO 693-2) 
6.2. Do you frequently speak a second language at home?

Yes, I speak:........... (Write in the language and code as ISO693-2)

No

Note:

ISO $3166-1$ is available at:

www.iso.org/iso/country_codes/iso_3166_code_lists.htm.

ISO 693-2 is available at www.loc.gov/standards/iso639-2.

\section{Conclusion}

- We have developed a battery of questions that facilitates the collection of ethnicity-related socio-demographic characteristics of relevance to social scientists. These characteristics include "legal status" measured via "citizenship",

- "residential status" in the case of respondents who are not citizens of the country of residence at the time of the survey, and

- "immigrant background" determined on the basis of the country of birth of the respondent and that of his or her mother and father.

These data serve to determine citizenship, country of origin, and, in the case of non-citizens, residential status. In a second step, the respondent's self-assignment to an ethnic population group is recorded. And finally, in the case of respondents with an immigrant background, the level of integration in the host country is determined by asking what languages they usually speak at home.

In terms of content, the questions offered here go beyond the typical core variable proposed, for example, by Eurostat for national censuses (2007, p. 24, p. 61-65). Nevertheless, we are of the opinion that, for cross-national comparison purposes, ethnicity should be measured using the above-mentioned six questions in order to cover the various dimensions of this complex of themes.

However, it is up to the user to decide whether to employ all six questions or only some of them if they suffice to capture ethnicity as a social background variable. By the same token, if the research focus is on ethnicity, the user may also decide to add new questions in order to go into greater depth.

\section{References}

[1] Akgündüz, A. (2008): Labour Migration from Turkey to Western Europe, 1960-1974. A Multidisciplinary Analysis. Aldershot and Burlington: Ashgate. 
[2] Alba, R. (2005): Bilingualism Persists, but English still Dominates. Migration Information Source http://www.migrationinformation.org/Feature/dislay.cfm?ID=282, (11 February 2009).

[3] Bade, K. and Oltmer, J. (Eds.) (1999): Aussiedler: Deutsche Einwanderer aus Osteuropa. Schriften des Instituts für Migrationsforschung und interkulturelle Studien (IMIS) der Universität Osnabrück, Vol. 8. Osnabrück.

[4] Billiet, J. (2002): Questions about national, subnational and ethnic identity. In: European Social Survey: Core Questionnaire Development. www.europeansocialsurvey.org/index.php?option=com_content\&view=article \&id=62\&Itemid=355 (12 Sept. 2009).

[5] Central Statistical Office (2007): Demographic Yearbook of Poland. http://www.stat.gov.pl/cps/rde/xbcr/gus/PUBL_PUBL_Demographic_yearboo k_of_Poland_2007.pdf (10 June 2009).

[6] Commission of the European Communities (2007): Proposal for a Regulation of the European Parliament and of the Council on population and housing censuses. Brussels, 23 February 2007.

http://eurlex.europa.eu/Notice.do? mode $=$ dbl\&lng $1=$ de,en $\& \operatorname{lang}=\& \operatorname{lng} 2=c s$, da,de,el,en,es,et,fi,fr,hu,it,lt,lv,mt,nl,pl,pt,sk,sl,sv,\&val=443972:cs\&page=\&h words=null (12 Sept. 2009).

[7] Czech Statistical Office (2001): 2001 Census Questionnaire. Persons. http://www.czso.cz/csu/cizinci.nsf/engkapitola/uvod (10 June 2009).

[8] Eurobarometer (2005): Eurobarometer 64.2, October-November 2005. Basic Bilingual Questionnaire. TNS Opinion \& Social.

[9] European Communities (2007): Task Force on Core Social Variables. Final report, Theme: Population and social conditions. Collection: Methodologies and working papers. Luxembourg: Office for Official Publications of the European Communities.

[10] European Social Survey (ESS) http://www.europeansocialsurvey.org/ (12 Sept. 2009).

[11] European Social Survey (2004): Source Questionnaire. Round 2, 2004/5. Final Version. ESS Document date: 21-07-04, Questions C16-C27.

[12] European Social Survey (2006a): Final Source Questionnaire. Round 3, 2006/7. Amendment 03. ESS Document date: 08-08-06, Questions C24-C36.

[13] European Social Survey (2006b): ESS DATA. ESS3-2006. Questionnaire. http://ess.nsd.uib.no/index.jsp?year=2007\&country=\&module=questionaires (12 Sept. 2009).

[14] European Value Study (2008): European Value Study. Master Questionnaire 2008. Final Version, 7 March 2008. www.europeanvaluesstudy.eu/evs/surveys/survey-2008/ masterquestionnaire.pdf (12 Sept. 2009). 
[15] General Secretariat of the National Statistical Service of Greece (2001): Population and Housing Census of 18 March 2001.

http://www.statistics.gr/eng_tables/s1101_sap_05_mt_01_y_en.pdf (12 Sept. 2009).

[16] Grand Duchy of Luxembourg, Statec, (2001): General Population Census 2001. Household and Dwelling Form. Model II.

[17] Heckmann, F. (1992): Ethnische Minderheiten, Volk und Nation. Soziologie inter-ethnischer Beziehungen. Stuttgart: Enke.

[18] Heckmann, F. (1999): Citizenship and Nation in Germany: Old and New Concepts. efms Paper No. 32.

[19] Hoffmann, D., Krauss, M., and Schwartz, M. (2000): Vertriebene in Deutschland. Interdisziplinäre Ergebnisse und Forschungsperspektiven. Munich: Oldenbourg.

[20] Hoffmeyer-Zlotnik, J.H.P. and Warner, U. (2009): Die Abfrage von "Ethnizität" in der international vergleichenden Survey-Forschung. Mannheim: Forschung Raum und Gesellschaft.

[21] Hungarian Central Statistical Office (2001): Population Census 2001. http://www.nepszamlalas.hu/eng/volumes/concepts.html

(12 Sept. 2009).

[22] Hungarian Central Statistical Office (2001): Population Census 2001. http://www.nepszamlalas.hu/eng/volumes/concepts.html (12 Sept. 2009).

[23] Istat (2001): General Population and Housing Census 2001. http://dawinci.istat.it/pl/index_eng.html (12 Sept. 2009).

[24] Jary, D. and Jary, J. (1991b): Ethnicity. In The Harper Collins Dictionary of Sociology. New York: Harper Collins Publishers Ltd., 151-152.

[25] Kaiser, M. (1985): Migration und Remigration: Das Beispiel Griechenland. In Mitteilungen aus der Arbeitsmarkt- und Berufsforschung, 18/4: 492-506.

[26] Leets, L., Clément, R., and Giles, H. (no year given): The ethnicity quandary: conceptual and measurement issues. Unpublished paper, cited by Billiet 2002.

[27] Malesevic, S. and Hall, J.A. (2005): Citizenship, ethnicity and nation-states. In: Calhoun, C., Rojek, C., and Turner B. (Eds): The SAGE Handbook of Sociology. London Thousand Oaks, New Delhi: Sage, 561-578.

[28] Marrus, M.R. (1985): The Unwanted: European Refugees in the 20th Century. Oxford: Oxford University Press.

[29] Messere, G. (2008): Die Erfindung des Gastarbeiters. Merzig: Gollenstein.

[30] Meyers Lexikon online (2009): Muttersprache.

http://lexikon.meyers.de/wissen/Muttersprache (12 Sept. 2009). 
[31] Office for National Statistics et. al. (2004): Census 2001. http://www.statistics.gov.uk/statbase/Product.asp?vlnk=12951 (12 Sept. 2009).

[32] Republic of Bulgaria, National Statistical Institute (2001): Population, Housing and Agricultural Holdings Census at 1 March, 2001. Census Questionnaire for Buildings, Dwellings and Population.

[33] Republic of Cyprus, Statistical Service (2001): Census of Population 2001. Questionnaire.

[34] Republic of Slovenia (1991): Constitution of the Republic of Slovenia, OJ RS, No. 33/91-I, Article 61.

[35] Ruf, W. (2002a): Identität und Integration - Islamische Staatsbürgerschaft in Frankreich. In Blätter für deutsche und internationale Politik Nr. 5/2002: 594-601. http://www.werner-ruf.net/pdf/Migr_F_B1\%8Atter030302.pdf (11 February 2009).

[36] Ruf, W. (2002b): Die meisten Muslime in Frankreich finden Chirac und Jospin gut. Über das komplexe Verhältnis von Migration, Identität und Staatsbürgerschaft im westlichen Nachbarland. Frankfurter Rundschau, 3 April 2002.

[37] Schneider, J. (2005): Aussiedler. In Migration. Migration und Integration in Deutschland. Bundeszentrale für politische Bildung 15 March 2005.

[38] Statistical Office of the Republic of Slovenia (2002): Census of Population, Households and Housing in the Republic of Slovenia in 2002. Census Questionnaire for Persons. P-3. www.gov.si.popis2002.

[39] Statistical Office of the Slovak Republic (2007a): Census of Population and Housing. http://portal.statistics.sk/showdoc.do?docid=4486 (12 Sept. 2009).

[40] Statistics Estonia (2000): Population and Housing Census. http://www.stat.ee/26304 (12 Sept. 2009).

[41] Statistics Finland (2001): Population Census 2000 Handbook. http://tilastokeskus.fi/tk/he/vaestolaskenta/vaestolask_vl2000_en.html (12 Sept. 2009).

[42] Statistics Lithuania, (2001b): Population Census. Census Questionaire. http://www.stat.gov.lt/en/pages/view/?id=1667 (12 Sept. 2009).

[43] Statistics Norway (2001): The Population and Housing Handbook 2001. http://www.ssb.no/english/subjects/02/01/doc_200502_en/doc_200502_en.pdf (12 Sept. 2009).

[44] Statistische Ämter des Bundes und der Länder (2008): Stichprobenerhebung über die Bevölkerung und den Arbeitsmarkt. Mikrozensus 2008 und Arbeitskräftestichprobe der Europäischen Union 2008. Fragebogen.

[45] Tajfel, H. (Ed., 1978): Differentiation between Subgroups. London: Academic Press. 
[46] The European Parliament and the Council of the European Union (2007): The Regulations (EC) No 862/2007 of the European Parliament and of the Council of 11 July 2007 on Community Statistics on Migration and International Protection and Repealing Council Regulation (EEC) No 311/76 on the compilation of statistics on foreign workers.

[47] Wren, C.S. (1995): Resettling Refugees: U.N. Facing New Burden. In: New York Times, 24 November 1995.

[48] Zentralarchiv für Empirische Sozialforschung (2004): ISSP 2004. Citizenship. Codebook. ZA Study 3950. 